\title{
Antipathogenic potentiality of fluorescent pseudomonads for the management of rice sheath blight pathogen, Rhizoctonia solani
}

\section{SNEHAL J. SHINDE AND S.K. PRASHANTHI}

Department of Biotechnology, College of Agriculture, University of Agricultural Sciences, DHARWAD (KARNATAKA) INDIA

Email : prashanthi.sangam@gmail.com

\begin{abstract}
Sheath blight (ShB) of rice is an important soil-borne fungal disease caused by Rhizoctonia solani (Kuhn) causing up to 40 per cent of yield losses annually. The present investigation was aimed to study the effect of Fluorescent pseudomonads on sheath blight management in rice and impact on plant growth. Fifteen different pseudomonad isolates were evaluated for their antagonistic activity against Rhizoctonia solani isolates under in vitro condition. Per cent inhibition of mycelial growth of $R$. solani by pseudomonads ranged from 74-100. All the isolates showed antagonism against the pathogen. Five strains, 12, 20, 19, soy2 and soy6 were found potent with 87-100 per cent inhibition of mycelial growth. They were further evaluated in greenhouse as seed treatment, soil application, foliar spraying and combined (seed+soil+foliar application) treatment for sheath blight control. Fluorescent pseudomonad isolate 19 was found potent and promising as it reduced the disease to the maximum extent and stimulated plant and root growth.
\end{abstract}

Key words : Rice, Rhizoctonia solani, Sheath blight, Fluorescent pseudomonads, Biocontrol

How to cite this paper : Shinde, Snehal J. and Prashanthi, S.K. (2014). Antipathogenic potentiality of fluorescent pseudomonads for the management of rice sheath blight pathogen, Rhizoctonia solani. Asian J. Bio. Sci., 9 (2) : 255-260. 